\title{
Diazotrophic bacteria isolated from wild rice Oryza glumaepatula (Poaceae) in the Brazilian Amazon
}

\author{
Paulo Ivan Fernandes Júnior ${ }^{1}$, Gilmara Maria Duarte Pereira ${ }^{2}$, Liamara Perin ${ }^{3}$, Luana Mesquita
} da Silva ${ }^{4}$, Alexandre Cardoso Baraúna ${ }^{2}$, Francilene Muniz Alves ${ }^{5}$, Samuel Ribeiro Passos ${ }^{6} \&$ Jerri Édson Zilli ${ }^{7}$

1. Embrapa Semiárido, BR 428, Km 152, Zona Rural, CEP 56302-970, Petrolina, PE, Brazil; paulo.ivan@embrapa.br

2. Universidade Federal de Roraima; Centro de Estudos da Biodiversidade, Avenida Capitão Ene Garcez, 2314, Aeroporto CEP 69304-000, Boa Vista, RR, Brazil; gmdpereira@hotmail.com; alexandre.barauna.bio@gmail.com

3. Instituto Federal de Educação, Ciência e Tecnologia de Sergipe, Campus Glória, Rod. Rota do Sertão, s/nº, CEP 49680-000, Nossa Senhora da Glória, SE, Brazil; liaperin@yahoo.com.br

4. Fundação Nacional de Saúde, Av. Capitão Ene Garcez, 1636, São Francisco, CEP 69304-000, Boa Vista, RR, Brazil; bioluana-rr@hotmail.com

5. Faculdade Cathedral de Ensino Superior, Av. Luís Canuto Chaves, 293, Caçari, CEP 69.307-053, Boa Vista, RR, Brazil; francilenemuniz_bio@hotmail.com

6. Universidade Federal Rural do Rio de Janeiro, Instituto de Agronomia, Departamento de Solos, Rod. BR 465 km 07 , Ecologia, CEP 23890-000, Seropédica, RJ, Brazil; passos.samuel@gmail.com

7. Embrapa Agrobiologia, Rod. BR 465 km 07, Ecologia, CEP 23890-000, Seropédica, RJ, Brazil; jerri.zilli@embrapa.br

\section{Received 23-III-2012. Corrected 10-IX-2012. Accepted 18-X-2012.}

\begin{abstract}
Bacterias diazotróficas aisladas de arroz silvestre Oryza glumaepatula (Poaceae) en la Amazonia brasileña. The association of wild grasses with diazotrophic bacteria in Brazilian biomes is poorly understood. The isolation and characterization of bacteria associated with wild grasses can contribute to understand the diazotrophic ecology as well as to identify bacteria with biotechnological applications. In this study, we isolated and characterized diazotrophic bacterial isolates from Oryza glumaepatula collected in Cerrado and Forest areas of the Amazon in Roraima State, Brazil. Healthy O. glumepatula plants were collected at five sampling sites at Forest and seven at Cerrado, respectively. The plants were collected at the Cerrado areas in September 2008 while the Forest plants were collected in June/2008 and April/2009. The plants and the soil adhering to the roots were transferred to pots and grown for 35 days in greenhouse conditions. During the harvest, the shoots and the roots were crushed separately in a saline solution; the suspension was diluted serially and inoculated in Petri dishes containing Dyg's medium. All distinct bacterial colonies were purified in the same medium. The diazotrophic capacity of each bacterium in microaerophilic conditions was assessed in semisolid BMGM medium. In addition, the pellicles forming bacterial isolates were also evaluated by PCR amplification for $n i f H$ gene. The diversity of nif $\mathrm{H}^{+}$bacteria was analyzed by Box-PCR fingerprinting. For selected strains, the growth promoting capacity of $O$. sativa as a model plant was also evaluated. A total of 992 bacterial isolates were obtained. Fiftyone bacteria were able to form pellicles in the semisolid medium and 38 also positively amplified the $360 \mathrm{bp}$ nif $\mathrm{H}$ gene fragment. Among the 38 nif $\mathrm{H}^{+}$isolates, 24 were obtained from the shoots, while 14 originated from the roots. The Box-PCR profiles showed that the bacterial isolates obtained in this study presented a low similarity with the reference strains belonging to the Herbaspirillum, Azospirillum and Burkholderia genus. The growthpromoting ability was confirmed for at least five isolates. For these bacteria, the root and shoot growing results showed higher increases when compared to those observed in plants inoculated with the evaluated reference strains. These results indicate that $O$. glumaepatula is colonized by a high diverse diazotrophic community in
\end{abstract}


the Brazilian Amazon. Further investigations are now being carried out to determine the taxonomic positions of these isolates and their growth promoting mechanisms. Rev. Biol. Trop. 61 (2): 991-999. Epub 2013 June 01.

Key words: biological nitrogen fixation, plant growing promoting bacteria, non-symbiotic associations, microbial ecology, inoculant.

Interaction among diazotrophic bacteria and non-legume plants is widely described in scientific literature. The association of several non-legumes species, especially members of the Poaceae family, and diazotrophic bacteria have already been well studied and characterized (Baldani et al. 2009). In Brazil, the studies regarding the interactions among the associative diazotrophs and grasses is well established to crop plants such as rice, maize, sugar-cane and wheat (Baldani \& Döbereiner 1980, Oliveira et al. 2006, Hungria et al. 2010). As a result of the information acquired in this field, the use of inoculants has recently been recommended for several grasses like maize, rice, wheat and sugar-cane (Silva et al. 2009, Hungria et al. 2010). Despite the fact that research on grasses and diazotrophic bacteria association has increased, there is a lack of knowledge regarding these associations for wild plant species in Brazil. Few recent studies have shown large diversity of cultivated bacteria isolated from wild grasses in Brazil (Brasil et al. 2005, Fernandes Júnior et al. 2011, 2012).

In Brazil four species of wild rice have been identified and among them Oryza glumaepatula Steud (Poaceae) is now indicated as a potential gene source to transfer to rice cultivars by crop breeding, due their similarity in genomic structure (Rangel et al. 2006, Rosa et al. 2006, Veasey et al. 2011). Although the potential of $O$. glumaepatula as a genetic resource was shown, the interaction of this species with soil microorganisms remains largely unknown and must be investigated. Recent studies have shown that the Amazonian wild rice $O$. glumaepatula is able to associate with dark septate endophytic (DSE) fungi that are able to colonize the roots of $O$. glumaepatula and O. sativa (Pereira et al. 2011, Ribeiro et al. 2011).
Regarding the diazotrophic community, other studies have also shown that screening of diazotrophic bacteria isolated from wild rice species $O$. alta Swallen and O. rufipogon Griff revealed a diverse and efficient diazotrophic community in Asia (Peng et al. 2008, Zhang et al. 2008, Tan et al. 2009). These results indicate the wild rice species as sources of several microorganisms with biotechnological potential. The search for efficient diazotrophic bacteria associated with wild grasses may also result in the obtainment of bacterial strains adapted to harsh conditions and applicable to the inoculation of crop plants.

In spite of the diazotrophic ability of the microbial community associated with Amazonian O. glumaepatula (Prast \& Esteves 1998), there is no information regarding its bacteria isolation and characterization. The aim of this study was to evaluate the diversity and the growth promotion ability of diazotrophic bacteria isolated from $O$. glumaepatula obtained in Forest and Cerrado areas in the Amazon forest, in Roraima State, Brazil.

\section{MATERIALS AND METHODS}

Sample sites, plant cultivation and bacteria isolation: Healthy plants of Oryza glumaepatula were collected at the Cerrado and Forest areas in Roraima State, Brazil. At the Cerrado, seven sites $\left(02^{\circ} 59^{\prime} 6.8^{\prime \prime} \mathrm{N}\right.$ $60^{\circ} 21^{\prime} 7.4$ ” W; 02 $59^{\prime} 17.5^{\prime \prime} \mathrm{N}$; 60²3'26.9” W; $02^{\circ} 58^{\prime} 51.0$ ' $\mathrm{N}-60^{\circ} 23^{\prime} 20.8^{\prime \prime} \mathrm{W}$; 02 $57^{\circ} 58.7^{\prime \prime}$ $\mathrm{N}$ - 60²1'39.9” W; 02॰57'39.1” N; $60^{\circ} 21^{\prime} 20.8^{\prime \prime} \mathrm{W} ; 02^{\circ} 55^{\prime} 43.1^{\prime \prime} \mathrm{N}$; 60²4'02.0” $\mathrm{W}$ and $03^{\circ} 02^{\prime} 03.0^{\prime \prime} \mathrm{N}-60^{\circ} 19^{\prime} 12.9 \mathrm{~W}$ ) were sampled in September/2008. For forest sampling, five sites $\left(01^{\circ} 25^{\prime} 44.2^{\prime \prime} \mathrm{N}-60^{\circ} 59^{\prime} 0.3\right.$ " $\mathrm{W} ; 01^{\circ} 25^{\prime} 10.2^{\prime \prime} \mathrm{N}-60^{\circ} 59^{\prime} 1.7^{\prime \prime} \mathrm{W}$; 01²4'1.1" 
$\mathrm{N}-60^{\circ} 59^{\prime} 1,7^{\prime \prime} \mathrm{W} ; 0^{\circ} 24^{\prime} 2.4^{\prime \prime} \mathrm{N}-60^{\circ} 59^{\prime} 9.2^{\prime \prime}$ $\mathrm{W}$ and $01^{\circ} 24^{\prime} 56.7^{\prime \prime} \mathrm{N}-60^{\circ} 59^{\prime} 13.8^{\prime \prime} \mathrm{W}$ ) were sampled in June/2008 and April/2009. At both sites at least three clumps of plants were collected for each sample. These samples were packed into plastic bags with the soil adhering to the roots and transported to the laboratory.

The plants were transplanted to pots with the soil adhering to the roots and were maintained in a greenhouse for 35 days. During this period, the plants received weekly $200 \mathrm{~mL}$ of nitrogen free Hoagland solution (Hoagland \& Arnon 1950) and aiming to increase the vegetative growth of these plants, $20 \mathrm{mM}$ ammonium sulfate was applied on the $7^{\text {th }}$ and $21^{\text {st }}$ day after the transplantation. On the $35^{\text {th }}$ day after transplanting, the plants were collected and cut into shoots and roots. The roots and shoots were then washed separately with tap water and finally washed with sterile distilled water.

Ten grams of each sample (root or shoot) per pot were crushed in a common blender containing $90 \mathrm{~mL}$ of saline solution $\mathrm{NaCl} 8.5 \mathrm{~g} / \mathrm{L}$. The suspensions were serially diluted until $10^{-6}$ and aliquots of $100 \mu \mathrm{L}$ were, in duplicate, were spread on Petri dishes containing Dyg's medium (Rodrigues Neto et al. 1986). The Petri dishes were incubated in the dark at $28^{\circ} \mathrm{C}$ for ten days and, after this period, the colonies, which presented distinct phenotypical characteristics on the same plate, were considered as a single isolate and purified also in the Dyg's medium.

Assessment of diazotrophic capacity: To assess qualitatively the biological nitrogen fixation (BNF) capacity of the bacteria in microaerophilic conditions (Döbereiner et al. 1995, Mantilla-Paredes et al. 2009, Sgroy et al. 2009, Silva \& Melloni 2011), the purified isolates were inoculated, in duplicate, in assay tubes containing $5 \mathrm{~mL}$ of BMGM semisolid medium (Estrada de los Santos et al. 2001) and incubated for ten days at $28^{\circ} \mathrm{C}$. After this period, the pellicle formation was analyzed below the medium surface and the isolates that presented this characteristic were inoculated twice in the same medium to confirm the diazotrophic ability. The identified pellicle-forming isolates were considered as potential diazotrophs and were selected for further evaluation.

Molecular fingerprinting of the bacterial isolates: The pellicle-forming isolates where grown in liquid Dyg's medium with constant shaking of 100 revolutions per minute (rpm) during 24 hours. The culture broth was used for the DNA extraction using the DNA extraction kit "RTP Bacteria DNA" (Invitek, Berlin, Germany) according to the manufacturer's instructions. To amplify the nifH gene the primers PolF (TGCGAYCCSAARGCBGACTC) and PolR (ATSGCCATCATYTCRCCGGA) were used, and PCR conditions described by Poly et al. (2001) adapting the annealing temperature to 55,59 or $62^{\circ} \mathrm{C}$. The $\mathrm{PCR}$ to $n i f \mathrm{H}$ was carried out for all 51 pellicule-forming isolates at three different annealing temperatures as described above. The PCR products were submitted to electrophoresis in agarose gel $(12 \mathrm{~g} / \mathrm{L} ; 120 \mathrm{~V}$ by $30 \mathrm{~min})$ followed by ethidium bromide $(0.5 \mathrm{~g} / \mathrm{L})$ staining and observation in a UV chamber. The amplifications were considered positive to the nif $\mathrm{H}$ gene $\left(n i f \mathrm{H}^{+}\right)$when it was possible to observe the fragment with around $360 \mathrm{bp}$ in at least one annealing temperature tested. As a positive control, the BR 11001 strain (Azospirillum brasilense) was also evaluated.

The nif $\mathrm{H}^{+}$isolates were again evaluated according to their capacity to fix nitrogen in micro-aerophilic conditions now in three semi-selective semisolid media: NFb; LGI and JMV (Döbereiner et al. 1995). This assay was performed in triplicate and it was considered as a positive strain whenever the characteristic pellicle occurred in all replications.

The $n i f \mathrm{H}^{+}$isolates were also analyzed by Box-PCR profiles. For PCR amplification, the A1 primer (CTACGGCAAGGCGACGCTGACG) (Versalovic et al. 1994) was used. The PCR and electrophoresis conditions were adapted from those proposed by Hungria et al. (2008). The gel image was analyzed through the Bionumerics software (Applied Maths, Kortrijk, Belgium) following the clustering by unweighted pair group method with 
arithmetic mean (UPGMA) and the Pearson correlation index.

Plant growth assay: To evaluate the ability of selected bacterial isolates to promote the plant growth, an assay was performed using the rice (O. sativa) as a model plant. The growth promotion ability of seven selected bacterial isolates, obtained from $O$. glumaepatula (ERR 1019, ERR 1021, ERR 1028, ERR 1029, ERR 1030, ERR 1038 and ERR 1042), one Herbaspirillum seropedicae (BR 11175) and an A. brasilense (BR 11001), were evaluated. An uninoculated treatment was used additionally as absolute control. The bacteria were grown in Dyg's liquid medium during $48 \mathrm{~h}$ with constant shaking at $100 \mathrm{rpm}$ and $500 \mu \mathrm{L}$ of each bacterial broth was used as an inoculant.

The rice seeds (cv. BRS Roraima) were superficially disinfected with ethanol, hydrogen peroxide followed by ten washings with sterile distilled water and germinated previously in Petri dishes containing agar-water medium. The seedlings were transferred to assay tubes (one plant per tube) containing $50 \mathrm{~mL}$ of solid Hoagland medium (Hoagland \& Arnon 1950) and were inoculated with the corresponding bacteria. The tubes were kept in an incubation room with a $12 \mathrm{~h}$ photoperiod and the temperature ranged from 26 to $28^{\circ} \mathrm{C}$. The experiment was conducted with a completely random design with four replicates.

Thirty days after inoculation, the plants were collected and the shoots were separated from the roots. The roots and shoots were washed and dried at $65^{\circ} \mathrm{C}$ for $72 \mathrm{~h}$. The shoot, root and total dry mass were evaluated. The data were analyzed by variance analysis and the averages separated by the Scott-Knott $(\mathrm{p}<0.05)$.

\section{RESULTS}

Bacterial isolation and BNF assessment: In order to assess the higher bacterial diversity inhabiting the tissues of Oryza glumaepatula, we previously isolated the bacteria in the solid medium. This approach allowed to obtain a large number of different bacterial phenotypes reaching a total of 992 isolates (Table 1) of which fifty one were pellicle-forming bacteria, i.e., possessed the capacity to fix nitrogen in micro-aerophilic conditions assessed in semisolid BMGM medium. This amount, therefore, indicated that around 5\% of the bacteria obtained are pellicle-forming. The percentage $(5 \%)$ of diazotrophic bacteria found in this study agrees with other studies that have shown similar ranges from wild or cultivated rice genotypes with low breeding improvement, applying the same strategy adopted in this study (the isolation and purification of bacteria previously in the solid medium) (Barraquio et al. 1997, Stoltzfus et al. 1997).

Molecular fingerprinting: The PCR reaction showed that 38 bacteria presented positive amplification to the fragment of around $360 \mathrm{bp}$, the size expected for the nif $\mathrm{H}$ gene (Fig. 1). The bacterial isolates that did not present positive amplification of nifH gene were considered nif $\mathrm{H}^{-}$while the isolates with positive amplification to the $360 \mathrm{bp}$ fragment were considered nif $\mathrm{H}$ positive $\left(\right.$ nif $\left.\mathrm{H}^{+}\right)$.

The analysis of the capacity of the bacterial isolates to grow and fix nitrogen on three different media showed that, in the $\mathrm{NFb}$ and LGI media, only one bacterial isolate was not able to grow and fix nitrogen in microaerophilic conditions, while in the JMV medium, three of the 38 isolates were not able to grow and presented positive nitrogen fixation. The ability of the bacterial strains to grow and fix $\mathrm{N}$ in different media indicates the metabolic versatility

\section{TABLE 1}

Distribution of $n i f \mathrm{H}^{+}$isolates obtained from roots and shoots of Oryza glumaepatula in Forest and Cerrado areas in the Amazon, Roraima State, Brazil

\begin{tabular}{lccc}
$\begin{array}{c}\text { Sampling } \\
\text { area }\end{array}$ & $\begin{array}{c}\text { Plant } \\
\text { tissue }\end{array}$ & $\begin{array}{c}\text { Number } \\
\text { of isolates }\end{array}$ & $\begin{array}{c}\text { nif } \mathrm{H}^{+} \\
\text {isolates }\end{array}$ \\
Forest & Shoot & 118 & 6 \\
& Root & 107 & 4 \\
Cerrado & Shoot & 318 & 18 \\
Total & Root & 449 & 10 \\
& & 992 & 38 \\
\hline
\end{tabular}




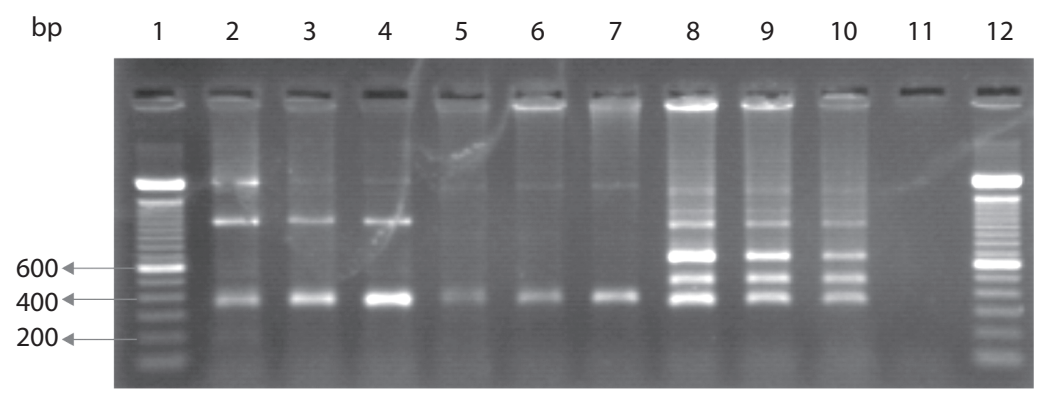

Fig. 1. Amplification of nif $\mathrm{H}$ gene using the PolF and PolR primers using 55 (lanes 2, 5 and 8); 59 (lanes 36 and 9) and $62{ }^{\circ} \mathrm{C}$ (lanes 4, 7 and 10) of annealing temperatures. Reference strain BR 11001 (lines 2 to 4), isolate ERR1020 (lanes 5 to 7) and isolate ERR 1027 (lanes 8 to 10). Lane 11: negative control and lines 1 and 12 molecular marker. On the left side, the molecular weight of the marker used.

of these bacteria that were able to grow with positive $\mathrm{N}$ fixation in media with different $\mathrm{pH}$ and carbon sources (Mantilla-Paredes et al. 2009, Silva \& Melloni 2011).

The Box-PCR fingerprinting obtained from $n i f \mathrm{H}^{+}$isolates showed that most of the bacteria and also the reference strains present different profiles (Fig. 2), indicating a large genetic diversity of these bacteria. It was possible to observe 13 clusters with $60 \%$ of similarity. Some of these clusters were formed exclusively with isolates from Cerrado (clusters IV and XII), either from the roots and shoots, while groups I, III and VIII covered only isolates from the shoots. Other peculiarities observed referred to the four groups with

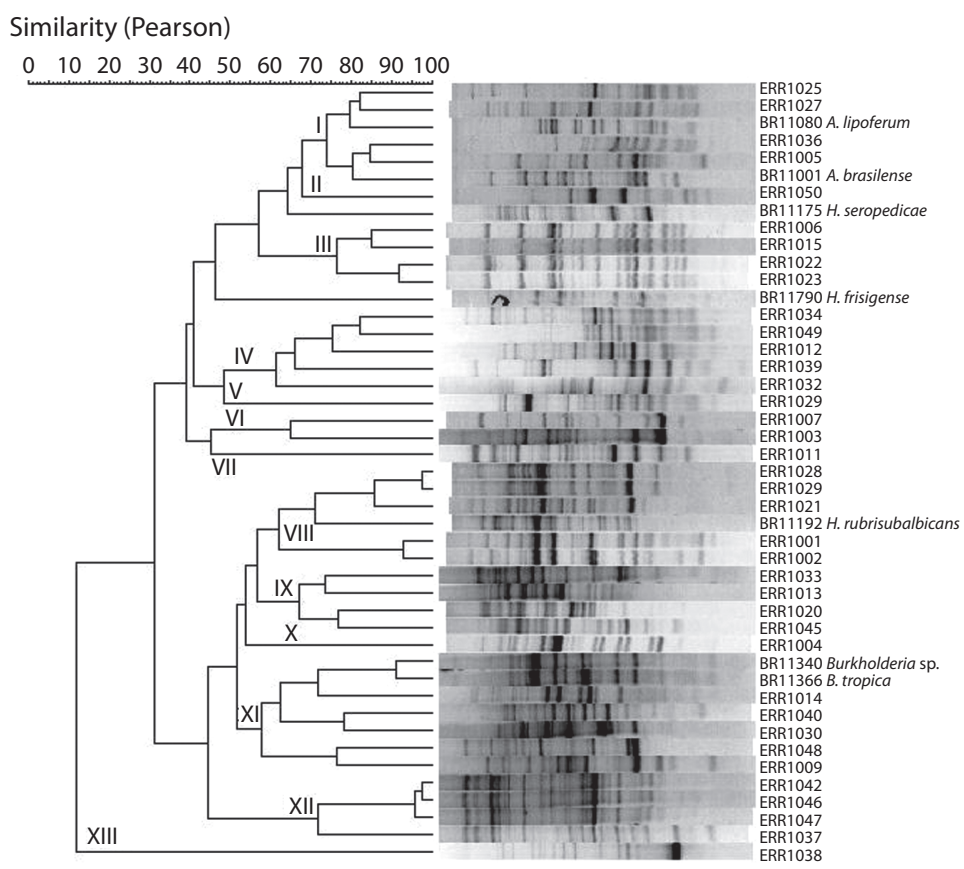

Fig. 2. Clustering of 38 diazotrophic bacterial isolates obtained from Oryza glumaepatula in the Brazilian Amazon using the Box-PCR technique. (UPGMA as clustering method applied and Pearson's coefficient). 
a single isolate (from Cerrado) with a high discrepancy to others (Fig. 2). All of the isolates obtained from the O. glumaepatula also showed low similarity to the reference strains indicating the genetic distance between the reference strains and the new bacteria.

Growth promoting assay: The ability of the bacterial strains to promote plant growth was evaluated and we observed that among the eight bacterial strains evaluated, four of them were able to increase the root dry mass compared to the absolute control and the positive controls inoculated with the BR 11001 ( $A$. brasilense) and BR 11175 (H. seropedicae) (Table 2). Three of the isolates were also able to increase the root dry mass of $O$. sativa more

TABLE 2

Growth promotion of Oryza sativa (cv. BRS Roraima) in vitro of seven bacterial isolates from O. glumaepatula and two reference strains (Herbaspirillum seropedicae, BR 11175 and Azospirillum brasilense, BR 11001)

\begin{tabular}{lccc}
$\quad \begin{array}{c}\text { Inoculation } \\
\text { treatment }\end{array}$ & \multicolumn{2}{c}{ Root } & $\begin{array}{c}\text { Shoot } \\
\text { dry weight (mg/plant) }\end{array}$ \\
ERR1029 & $180 \mathrm{a}^{*}$ & $107 \mathrm{~b}$ & $287 \mathrm{a}$ \\
ERR1028 & $153 \mathrm{a}$ & $117 \mathrm{a}$ & $270 \mathrm{a}$ \\
ERR1019 & $115 \mathrm{~b}$ & $72 \mathrm{~b}$ & $187 \mathrm{~b}$ \\
ERR1021 & $118 \mathrm{~b}$ & $115 \mathrm{a}$ & $233 \mathrm{a}$ \\
ERR1030 & $127 \mathrm{~b}$ & $123 \mathrm{a}$ & $250 \mathrm{a}$ \\
ERR1038 & $103 \mathrm{~b}$ & $103 \mathrm{~b}$ & $207 \mathrm{~b}$ \\
ERR1042 & $162 \mathrm{a}$ & $102 \mathrm{~b}$ & $263 \mathrm{a}$ \\
H. seropedicae & $148 \mathrm{a}$ & $108 \mathrm{~b}$ & $257 \mathrm{a}$ \\
A. brasilense & $155 \mathrm{a}$ & $97 \mathrm{~b}$ & $252 \mathrm{a}$ \\
Absolute control & $125 \mathrm{~b}$ & $98 \mathrm{~b}$ & $223 \mathrm{~b}$ \\
\hline
\end{tabular}

* Means followed by the same letter in the column do not differ from the Scott-Knott means test $(\mathrm{p}<0.05)$.

than BR 11001 and BR 11175. It must be pointed out that the isolate ERR 1028 was the only one able to increase both root and shoot biomass of the $O$. sativa plants, compared to the absolute and the inoculated controls. None of the evaluated reference strains achieved this capacity, which indicates the biotechnological potential of these bacteria.

\section{DISCUSSION}

Although only around 5\% of the bacterial isolates are able to fix nitrogen in micro-aerophilic conditions, some of these bacteria may not be isolated if the generally used strategy was applied to obtain the diazotrophic bacterial strains from crop species, during the first isolation step in semisolid medium (Stoltzfus et al. 1997); because the semisolid culture media normally used during these isolations is indicated to obtain the most studied and characterized diazotrophic bacteria such as Azospirillum (Baldani \& Döbereiner 1980); Herbaspirillum (Brasil et al. 2005); Burkholderia (Guimarães et al., 2007) and Sphingomonas (Videira et al. 2009).

Among all nif $\mathrm{H}^{+}$isolates, only 10 bacteria originated from the Forest area (ERR1001; ERR1002; ERR1013; ERR1014; ERR1015; ERR1021; ERR1003; ERR1020; ERR1050 and ERR1019), while 28 were obtained from Cerrado areas (ERR1005; ERR1040; ERR1004; ERR1012; ERR1022; ERR1023; ERR1033; ERR1037; ERR1045; ERR1049; ERR1007; ERR1009; ERR1011; ERR1027; ERR1032; ERR1046; ERR1047; ERR1034; ERR1036; ERR1025; ERR1038; ERR1048; ERR1029; ERR1028; ERR1042 and ERR1030). In addition, most of the bacteria, 24 isolates, were obtained from plant shoots, whereas only 14 from roots. This higher abundance of nif $\mathrm{H}^{+}$ bacteria in Cerrado areas compared to the Forest samples, indicates an ecological adaptation of the wild rice to the environmental conditions. In Cerrado areas, the O. glumaepatula normally presents an annual cycle and the plants originate from seeds that are spread in the soil at the end of the rainy season. The plant growth during this period follows the water availability, and when the water level decreases, the plants reach physiological maturity and disperse the seeds into the environment, which will germinate at the beginning of the next rainy season (Rosa et al. 2006). Instead, in Forest areas, during the larger part of the year, the plants are still in the water because of the drought and flood, which are less prominent. 
It is likely that in these conditions, the wellestablished Forest plants are less dependent on the associative bacteria then the younger Cerrado plants.

Normally, the studies that evaluate the isolation and characterization of nif $\mathrm{H}^{+}$bacteria from non-legume plants indicate that the majority of the isolates are obtained from root tissues (Videira et al. 2009, Vendan et al. 2010, Venieraki et al. 2011). However, there is evidence that during the vegetative development of grasses in plots where the water availability ranges from flood to drought, as in the Amazon, more diazotrophs must be isolated from shoots rather than from plant roots (Brasil et al. 2005, Koomnok et al. 2007).

Oryza species are widely colonized by bacteria belonging to the Herbaspirillum, Burkholderia, Azospirillum and other species (Baldani et al. 2009). Genetic evaluations have shown that wild rice species are colonized by a higher diazotrophic community compared to O. sativa (Hurek \& Reinhold-Hurek 2005). As we observed in this study, previous evaluations have also shown the low similarity among the strains from wild Oryza, and the reference strains belonging to Herbaspirillum, Burkholderia and Azospirillum (Tan et al. 2009) indicating the presence of new bacteria. The characterization of bacteria from wild Oryza species has also been performed over the last few years and new species (Cheng-Hui \& Yokota 2005, Peng et al. 2008) and genera (Zhang et al. 2008) have been described.

DSE fungi were already isolated from Amazonian O. glumaepatula, which are able to colonize and promote the growth of $O$. sativa (Pereira et al. 2011, Ribeiro et al. 2011). In this study, we found that this species of wild rice is also colonized by diazotrophic plant growth-promoting bacteria with biotechnological potential. The $O$. glumaepatula has already been indicated as a source of genes for rice breeding programs (Rangel et al. 2006). The recently published studies evaluated the diversity of DSE fungi and the results found in the present study also indicate this species as a source of beneficial microorganisms that must be applied to produce inoculants for rice crops. Further studies are now being carried out to investigate the growth-promoting mechanisms of those bacteria and to evaluate their taxonomic position.

\section{ACKNOWLEDGMENTS}

To Conselho Nacional para o Desenvolvimento Científico e Tecnológico (CNPq) (MCT/ CNPq/CT-Amazonia 554022/2006-0) and Coordenação de Aperfeiçoamento de Pessoal de Nível Superior (CAPES) for financial support.

\section{RESUMEN}

La asociación de gramíneas silvestres con bacterias diazotróficas en los biomas brasileños es poco conocida. El aislamiento y caracterización de las bacterias asociadas con gramíneas silvestres puede contribuir a entender la ecología de las diazotróficas y bacterias con aplicaciones biotecnológicas. En este estudio, caracterizamos aislamientos bacterianos de diazotróficas de Oryza glumaepatula recolectadas en Cerrado y zonas boscosas de la Amazonía en el estado de Roraima, Brasil. Plantas sanas de O. glumepatula fueron recolectadas en cinco zonas boscosas y siete en Cerrado. Las plantas de Cerrado fueron recolectadas en septiembre 2008, mientras que las del bosque en Junio 2008 y Abril 2009. Las plantas y el suelo adherido a las raíces se transfirieron a macetas y se cultivaron durante 35 días en condiciones de invernadero. Durante la cosecha, los brotes y las raíces se trituraron por separado en una solución salina, la suspensión se diluyó en serie y se inocularon en placas Petri que contenían medio Dyg. Todas las colonias de bacterias se purificaron en el mismo medio. Se evaluó la capacidad diazotrófica de cada bacteria en condiciones microaerofílicas en medio semisólido BMGM. Además, los aislamientos bacterianos que formaron películas se evaluaron también mediante amplificación por PCR para el gen nifH. La diversidad de bacterias nif $\mathrm{H}^{+}$se analizó por Huella Genética utilizando la Reacción en Cadena de la Polimerasa. Para las cepas seleccionadas, la capacidad de promover el crecimiento de $O$. sativa como modelo de planta también se evaluó. Se obtuvo un total de 992 cepas bacterianas. Cincuenta y un bacterias fueron capaces de formar películas en el medio semisólido y 38 amplificaron positivamente el fragmento 360bp del gen nifH. De los 38 aislamientos de $n i f \mathrm{H}^{+}, 24$ fueron obtenidos de los brotes, mientras que 14 se originaron a partir de las raíces. Los perfiles de PCR-Box mostraron que los aislamientos bacterianos obtenidos en este estudio presentaron una baja similitud con las cepas de referencia pertenecientes a Herbaspirillum, Azospirillum y el género Burkholderia. La capacidad promotora del crecimiento fue confirmada por al menos cinco aislamientos. 
Para esta bacteria, la raíz y brote mostraron resultados de crecimiento mayores en comparación con los observados en las plantas inoculadas con las cepas de referencia. Estos resultados indican que $O$. glumaepatula es colonizada por una muy diversa comunidad diazotrófica en la Amazonia brasileña. Se están llevando a cabo otras investigaciones para esclarecer la taxonomía de estas cepas y sus mecanismos para promover el crecimiento.

Palabras clave: fijación biológica de nitrógeno, bacterias promotoras de crecimiento de plantas, asociaciones nosimbióticas, ecología microbiana, inoculante.

\section{REFERENCES}

Baldani, V.L.D. \& J. Döbereiner. 1980. Host-plant specificity in the infection of cereals with Azospirillum spp. Soil Biol. Biochem. 12: 433-439.

Baldani, J.I., K.R.S. Teixeira, S. Schwab, F.L. Olivares, A.S. Hemerly, S. Urquiaga, V.M. Reis, E.M. Nogueira, J.L. Simões-Araújo, L.E.B., Baldotto, L.H.B. Soares, F. Vinagre, V.L.D. Baldani, T.L.G. Carvalho, B.J.R. Alves, E.K. James, C.P. Jantalia, P.C.G. Ferreira, M.S. Vidal \& R.M. Boddey. 2009. Fixação Biológica de Nitrogênio em Plantas da Família Poaceae (antiga gramineae), p. 203-271. In M.R. Ribeiro, C.W.A. Nascimento, M.R. Ribeiro Filho \& E.R.B. Cantalice (eds.). Tópicos em Ciência do Solo. 1 ed. Sociedade Brasileira de Ciência do Solo, Viçosa, Brazil.

Barraquio, W.L., L. Revilla \& J.K. Ladha. 1997. Isolation of endophytic diazotrophic bacteria from wetland rice. Plant Soil 194: 15-24.

Brasil, M.S., J.I. Baldani \& V.L.D. Baldani. 2005. Ocorrência e diversidade de bactérias diazotróficas associadas a gramíneas forrageiras do pantanal sul matogrossense. Rev. Bras. Ci. Solo. 29: 179-190.

Cheng-Hui, X. \& A. Yokota. 2005. Azospirillum oryzae sp. nov., a nitrogen-fixing bacterium isolated from the roots of the rice plant Oryza sativa. Int. J. Syst. Evol. Microbiol. 55: 1435-1438.

Döbereiner, J., V.L.D. Baldani \& J.I. Baldani. 1995. Como isolar e identificar bactérias diazotróficas de plantas não-leguminosas. Brasilia: EMBRAPA-SPI: Itaguí: EMBRAPA-CNPAB. p. 19-25.

Estrada de los Santos, P., R. Bustillos-Cristales \& J. Caballero-Melado. 2001. Burkholderia a genus rich in plant-associated nitrogen fixers with wide environmental and geographic distribution. Appl. Environ. Microbiol. 67: 2790-2798.

Fernandes Júnior, P.I., S.T. Aidar, C.V. Morgante, C.A.T Gava, J.É. Zilli \& L.M.V. Martins. 2011. Diversidade fenotípica de bactérias diazotróficas associadas à gramínea tolerante à dessecação Tripogon spicatus na Caatinga. CD Rom In III Simpósio de Mudanças
Climáticas e Desertificação do Semiárido Brasileiro, Brazil.

Fernandes Júnior, P.I.; Aidar, S.T.; Gava, C.A.T.; Zilli, J.É.; Martins, L.M.V. 2012. Caracterização Fenotípica de bactérias diazotróficas associadas a Tripogon spicatus no Bioma Caatinga. Embrapa Semiárido, Petrolina, Brazil.

Guimarães, S.L., J.I. Baldani, V.L.D. Baldani \& J. JacobNeto. 2007. Adição de molibdênio ao inoculante turfoso com bactérias diazotróficas usado em duas cultivares de arroz irrigado. Pesq. Agropec. Bras. 42: 393-398.

Hoagland, D.R. \& D.I. Arnon. 1950 The water culture method of growing plants without soil. University of California, Berkeley, USA.

Hungria, M., R.J. Campo, E.M. Souza \& F.O. Pedrosa. 2010. Inoculation with selected strains of Azospirillum brasilense and A. lipoferum improves yields of maize and wheat in Brazil. Plant Soil 331: 413-425.

Hungria, M., L.M.O. Chueire, P. Menna \& E.V. Bangel. 2008. Caracterização genética de rizóbios e outras bactérias diazotróficas e promotoras do crescimento de plantas por BOX-PCR. Embrapa Soja, Londrina, Brazil.

Hurek, T. \& B. Reinhold-Hurek. 2005. Molecular ecology of $\mathrm{N}_{2}$-fixing microbes associated with gramineous plants: hidden activities of unknown bacteria, p. 173198. In D. Wearner \& W.E. Newton (eds.). Nitrogen fixation in agriculture, forestry, ecology, and the environment. Springer, Dordrecht, Netherlands.

Koomnok, C., N. Teaumroong, B. Rerkasem \& S. Lumyong, 2007. Diazotroph endophytic bacteria in cultivated and wild rice in Thailand. ScienceAsia 33: 429-435.

Oliveira, A.L.M., E.L. Canuto, S. Urquiaga, V.M. Reis \& J.I. Baldani. 2006. Yield of micropropagated sugarcane varieties in different soil types following inoculation with diazotrophic bacteria. Plant Soil 284: 23-32.

Mantilla-Paredes, A.J., G.I. Cardona, C.P. Peña-Venegas, U. Murcia, M. Rodríguez \& M.M. Zambrano. 2009. Distribuición de bacterias potencialmente fijadoras de nitrógeno y su relación con parámetros fisicoquímicos con tres coberturas vegetales en el sur de la Amazonia colombiana. Rev. Biol. Trop. 57: 915-927.

Peng, G., Q. Yuan, H. Li, W. Zhang \& Z. Tan. 2008. Rhizobium oryzae sp. nov., isolated from the wild rice Oryza alta. Int. J. Syst. Evol. Microbiol. 58: 2158-2163.

Pereira, G.M.D., K.G. Ribeiro, P.I. Fernandes Júnior, M.J.S. Vital, M.C.M. Kasuya \& J.É Zilli. 2011. Ocorrência de fungos endofíticos «dark septate» em raízes de Oryza glumaepatula na Amazônia. Pesq. Agropec. Bras. 46: 331-334. 
Poly, F., L.J. Monrozier \& R. Bally. 2001. Improvement in the RFLP procedure for studying the diversity of nif $\mathrm{H}$ genes in communities of nitrogen fixers in soil. Res. Microbiol. 152: 95-103.

Prast, A.E. \& F.A. Esteves. 1998. Diurnal variation rates of denitrification and nitrogen fixation of periphyton associated with Oryza glumaepatula Steud in an Amazonian lake. Hydrobiologia 189: 189-192.

Rangel, P.H.N., C. Brondani, J.R. Fonseca, S.C. Silva, R.R. Rabelo, J.A. Pereira \& P. Emílio. 2006. Mapeamento da distribuição geográfica das espécies brasileiras de Oryza, com vistas à conservação dos parentes silvestres e das variedades crioulas de arroz (O. sativa L.). In Parentes silvestres das espécies de plantas cultivadas. Ministério do Meio Ambiente, Brasília, Brazil.

Ribeiro, K.G., G.M.D. Pereira, C.A. Mosqueira, A.C. Baraúna, M.J.S. Vital, K. Silva \& J.É. Zilli. 2011. Isolamento, armazenamento e determinação da colonização por fungos dark septate a partir de plantas de arroz.Agro@mbiente 5: 97-105.

Rodrigues Neto, J., V.A. Malavolta Júnior \& O. Victor. 1986. Meio simples para o isolamento e cultivo de Xanthomonas campestris pv. citri tipo B. Summa Phytopathol. 12: 16.

Rosa, M.S., P.P. Santos \& E.A. Veasey. 2006. Caracterização agromorfológica interpopulacional em Oryza glumaepatula. Bragantia 65: 1-10.

Sgroy, V.; F. Cassan, O. Masciarelli, M.F. Del Papa, A. Lagares \& V. Luna. 2009. Isolation and characterization of endophytic plant growth-promoting (PGPB) or stress homeostasis-regulating (PSHB) bacteria associated to the halophyte Prosopis strombulifera. Appl. Microbiol. Biotechnol. 85: 371-381.

Silva, M.F., P.J. Oliveira, G.R. Xavier, N.G. Rumjanek \& V.M. Reis. 2009. Inoculantes formulados com polímeros e bactérias endofíticas para a cultura da cana-de-açúcar. Pesq. Agropec. Bras. 44: 1437-1443.

Silva, T.F. \& R. Melloni. 2011. Densidade e diversidade fenotípica de bactérias diazotróficas não simbióticas em solos da Reserva Biológica Serra dos Toledos, Itajubá (MG). Rev. Bras. Ci. Solo. 35: 359-371.

Stoltzfus, J.R., R. So, P.P. Malarvithi, J.K. Ladha \& F.J. De Bruijn. 1997. Isolation of endophytic bacteria from rice and assessment of their potential for supplying rice with biologically fixed nitrogen. Plant Soil 194: 25-36.

Tan, Z.Y., G.X. Peng \& P.Z. Xu. 2009. Diversity and high nitrogenase activity of endophytic diazotrophs isolated from Oryza rufipogon Griff. Chin. Sci. Bull. 54: 2839-2848.

Veasey, E.A., E.A. Bressan, M.I. Zucchi, R. Vencovsky, D.C. Cardim \& R.M. Silva. 2011. Genetic diversity of American wild rice species. Sci. Agric. 68: 440-446.

Vendan, R.T., Y.J. You, S.H. Lee \&Y.H. Rhee. 2010. Diversity of endophytic bacteria in ginseng and their potential for plant growth promotion. J. Microbiol. 48: 559-565.

Venieraki, A., M. Dimou, E. Vezyri, I. Kefalogianni, N. Argyris, G. Liara, P. Pergalis, I. Chatzipavlidis \& P. Katinakis. 2011. Characterization of nitrogen-fixing bacteria isolated from field-grown barley, oat, and wheat. J. Microbiol. 49: 525-534.

Versalovic, J., M. Schneider, F.J. De Bruijn \& J.R. Lupski. 1994. Genomic fingerprinting of bacteria using repetitive sequence-based polymerase chain reaction. Meth. Mol. Cell. Biol. 5: 25-40.

Videira, S.S., J.L. Simões-Araújo, L.S. Rodrigues, V.L.D. Baldani \& J.I. Baldani. 2009. Occurrence and diversity of nitrogen-fixing Sphingomonas associated with rice plants grown in Brazil. FEMS Microbiol. Lett. 293: 11-19.

Zhang, G.X., G.X. Peng, E.T. Wang, H. Yan, Q.H. Yuan, W. Zhang, X. Lou, H. Wu \& Z.W. Tan. 2008. Diverse endophytic nitrogen-fixing bacteria isolated from wild rice Oryza rufipogon and description of Phytobacter diazotrophicus. Arch. Microbiol. 189: 431-439. 
